\title{
Corals from Asturian substage in Cantabrian Mountains: A review
}

\author{
${ }^{1}$ Departamento de Paleontología, Facultad de Ciencias Geológicas, UCM, c/José Antonio Novais, 2. 28040 Madrid, Spain; *Corresponding \\ author:E-mail:sergrodr@geo.ucm.es,isrodr01@ucm.es \\ ${ }^{2}$ Departamento de Geología Sedimentaria y Cambio Medioambiental, Instituto de Geociencias, CSIC, UCM, c/José Antonio Novais, 2.28040 \\ Madrid, Spain \\ ${ }^{3}$ Departamento de Geografía y Geología, Facultad de Ciencias Biológicas y Ambientales, Universidad de León, Campus de Vegazana, s/n, \\ 24071 León, Spain
}

(Received: February 16, 2021; Revised accepted: June 23, 2021)

https://doi.org/10.18814/epiiugs/2021/021015

The subdivision of the Pennsylvanian divided the Namurian, Westphalian and Stephanian regional stages in substages named with letters. During the second half of the 20th Century, some of these substages were more properly defined. Westphalian $A, B$ and $C$ were defined as Langsettian, Duckmantian and Bolsovian. The Stephanian A was renamed as Barruelian and the transition between Westphalian and Stephanian as Cantabrian. The Westphalian $D$, defined in continental strata from Saar-Lorraine, was proposed to be substituted by the Asturian substage with the stratotype in the Cantabrian Mountains. An extensive documentation with assemblages and stratigraphic distribution of plants, fusulinids, brachiopods, corals, molluscs and ostracods was presented. But a formal definition of the stratotype was never proposed. The Asturian substage in the Cantabrian Mountains comprises both marine and terrestrial strata rich in fossils and allows easy correlations with other areas. Recent studies have improved the stratigraphic data and the knowledge on the coral assemblages, mainly in the eastern area of Asturias and Palencia. The entire coral assemblage from Asturian substage in the Cantabrian Mountains is composed of 48 named species and 20 species described in open nomenclature. The short stratigraphic range of many of them may be the basis for the characterization of the Asturian stage with corals. Although some species are endemic in the Cantabrian Mountains, there are some species that are also present in other regions of the Palaeotethys. At the generic level there are significant similarities that should be the basis for wider correlations with North America and East Asia.

\section{Introduction}

The Pennsylvanian chronostratigraphic global stages (Cohen et al.,
2011; Richards, 2013) are based in stratigraphic marine successions from Russia (Bashkirian, Moscovian, Kasimovian and Gzhelian). But the active Variscan orogeny during that time produced complex sedimentation environments (basins) that often are difficult to correlate. Because of that, many regional series, stages and substages have been defined in different continental areas. The chronostratigraphic regional stages in Western Europe were mainly based in continental successions and defined in several areas with diverse geological histories. Those areas are the Northern European Coal Belt, the Massif Central in France and the Cantabrian Mountains in Northwest Spain (see reports by Wagner and Winkler Prins, 1985a, b; 2016).

The early subdivision of the upper Carboniferous proposed by Jongmans and Pruvost (1950) divided the Namurian, Westphalian and Stephanian in substages named with letters (Namurian, A, B, and C; Westphalian, A, B, C, and D, and Stephanian, A, B, and C). However, along the second half of the 20th Century, some of these substages were more accurately defined, became named and stratotypes were proposed. So, Westphalian A, B and C were defined as Langsettian, Duckmantian and Bolsovian based on the East Pennines Coalfield in Northern England (Owens et al., 1985; Waters et al., 2011). The Stephanian A was formally renamed the Barruelian Substage with stratotype in southern part of the Cantabrian Mountains (north of the Palencia province). The identification of Stephanian strata older than Barruelian and the absence of an equivalent succession in the Massif Central led to the definition of the Cantabrian Substage. It is again based in successions in the southern Cantabrian Mountains (Wagner and Winkler Prins, 1985a; Engel, 1989). Thus, only Stephanian B and C and Westphalian D remained as substages without a modern definition. The Westphalian D, defined in continental strata from Saar-Lorraine, was proposed to be substituted by the Asturian substage (Wagner et al., 2002), and a mixed marine/terrestrial stratotype containing abundant fossil fauna and flora was suggested. It allows excellent correlation with successions, both marine and continental, of similar age in other regions. Wagner et al. (2002) developed an extensive documentation including the description of the fossil assemblages and stratigraphic distribution of several fossil groups: plants, fusulinids, brachiopods, corals, molluscs and ostracods. A later report by Gandl (2011) enlarged 
the data-base with the inclusion of the trilobites distribution, but they never presented a formal proposal with the definition of a stratotype. But, the Asturian substage has been mostly accepted, and the name used by many authors (Oplustil and Cleal, 2007; Dimitrova et al., 2010; Cleal et al., 2011).

In the compilation of Wagner et al. (2002) the record of corals was incomplete; new stratigraphic data allow more precision in defining horizons and recent studies have increased the number of coral taxa, mainly of tabulates (Coronado and Rodríguez, 2014). The present paper is an homage to the authors of the first compilation and shows a more comprehensive relation of the coral distribution in the Asturian substage from Cantabrian Mountains. That kind of compilations is crucial for the subsequent definition of stages or systems. A good example of that is in Comas-Rengifo et al. (2015), whose analysis of brachiopod assemblages was used for the later definition of the base of the Toarcian in Peniche, Portugal (Rocha et al., 2016).

\section{Stratigraphy}

The Asturian substage in Cantabrian Mountains includes both marine and terrestrial strata. The sedimentation was syntectonic and took place in different domains and environments. Asturian sediments occur only in the central and eastern regions of Asturias, in the Liébana Valley (Cantabria) and in the northern Palencia. They are absent in western Asturias and northern León (Fig. 1), because those regions were uplifted and eroded during the Variscan orogeny. The central part of Asturias was covered by a marine-paralic basin (Central Asturian coal basin). It shows classical cyclothems with alternation of siliciclastic rocks, coal seams and less common limestone beds sedi- mented in a broad foreland basin. It comprises the upper part of the Lena Group (Caleras and Generalas formations, with many limestone beds and some coal beds); and the lower part of the Sama Group (San Antonio and Maria Luisa formations without limestone and more abundant conglomerates and sandstones) (Leyva and Gervilla, 1983; Colmenero et al., 2002). The proposed type section near the Riosa village is located in that area and settled along an old mining railway (Wagner et al., 2002). In northern Palencia, the Vergaño Formation and its equivalent in the Casavegas syncline are mainly siliciclastic (Fig. 2). But limestone beds are usually thicker and more common than in the Central coal basin, receiving specific names (Cotarraso Limestone, Sierra Corisa Limestone, Casavegas Limestone, Lores limestone, etc.) (Van Ginkel, 1965; Van den Graaf, 1971). The sedimentation in eastern Asturias is composed mainly of limestones developed in calcareous platforms with local intercalations of siliciclastic rocks (Fig. 2). Two different areas yielded corals: the coast cliffs at Cuevas de Mar and Playa de la Huelga, where the Cuera limestone shows siliciclastic intercalations (Navarro et al., 1986) and the Picos de Europa mountainous region, where the Picos de Europa Formation is completely calcareous. All areas contain well-exposed sections rich in paleontological content.

The presence of terrestrial and marine assemblages combined in the same sections allows an easy correlation with the previous Westphalian D defined in terrestrial facies from Saar-Lorraine and other basins in western Europe. Also with the global stages based in marine facies from Moscovian platform. The Asturian substage may be correlated with the Westphalian D from Central and western Europe, with the upper part of the Podolskian and the lower part of the Myachkovian substages from Russia and Ukraine. It also coincides with the middle part of the Desmoinesian stage from North America and with the upper

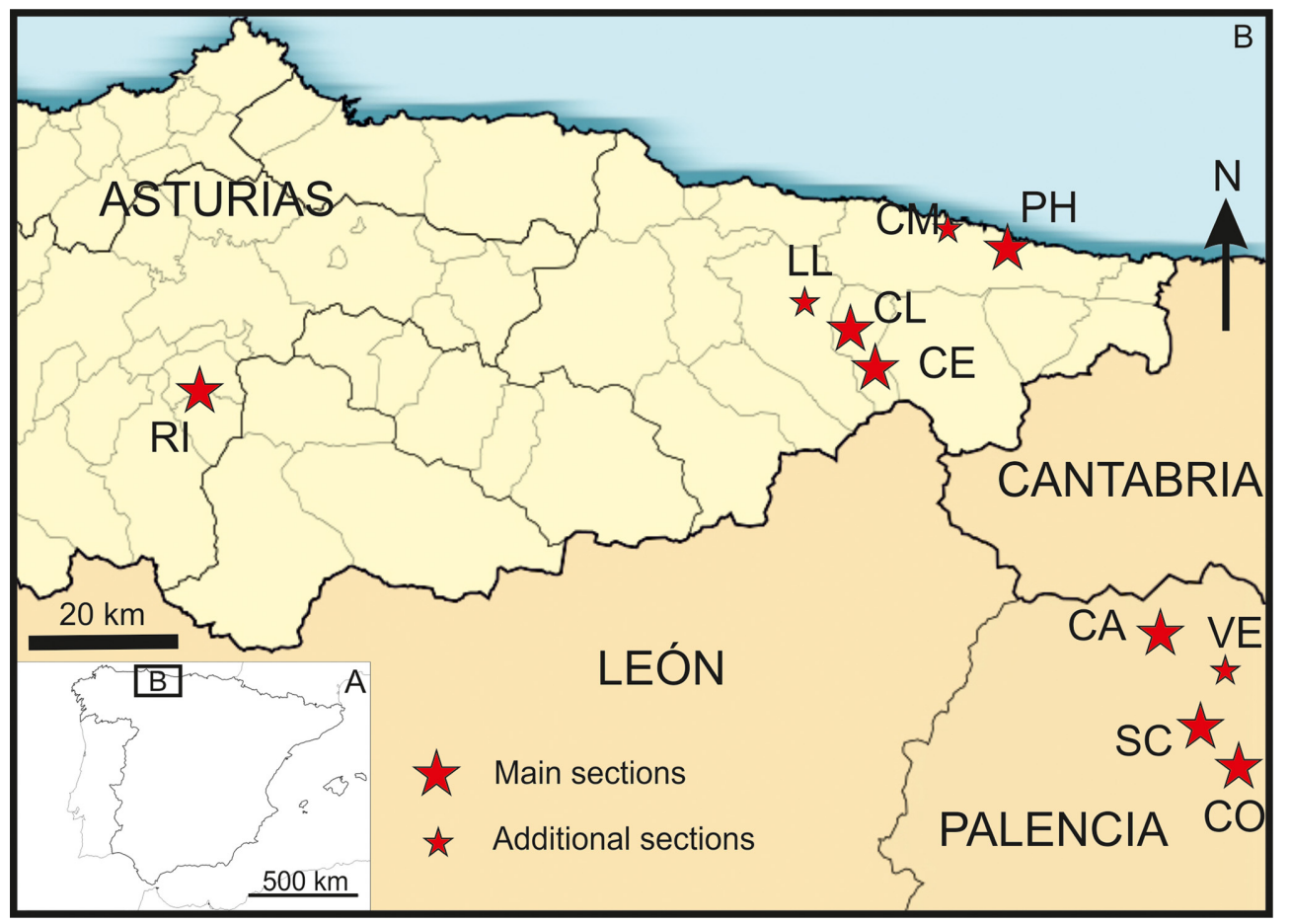

Figure 1. Location of main outcrops yielding Asturian corals in Cantabrian Mountains. Asturias: CE - Cuesta Espinera, CM - Cuevas de Mar, CL - Carretera Lagos, LL -Llacerias, PH - Playa de la Huelga, RI-Riosa; Palencia: CA -Casavegas, CO-Cotarraso, SC-Sierra Corisa, VE-Vergaño. 


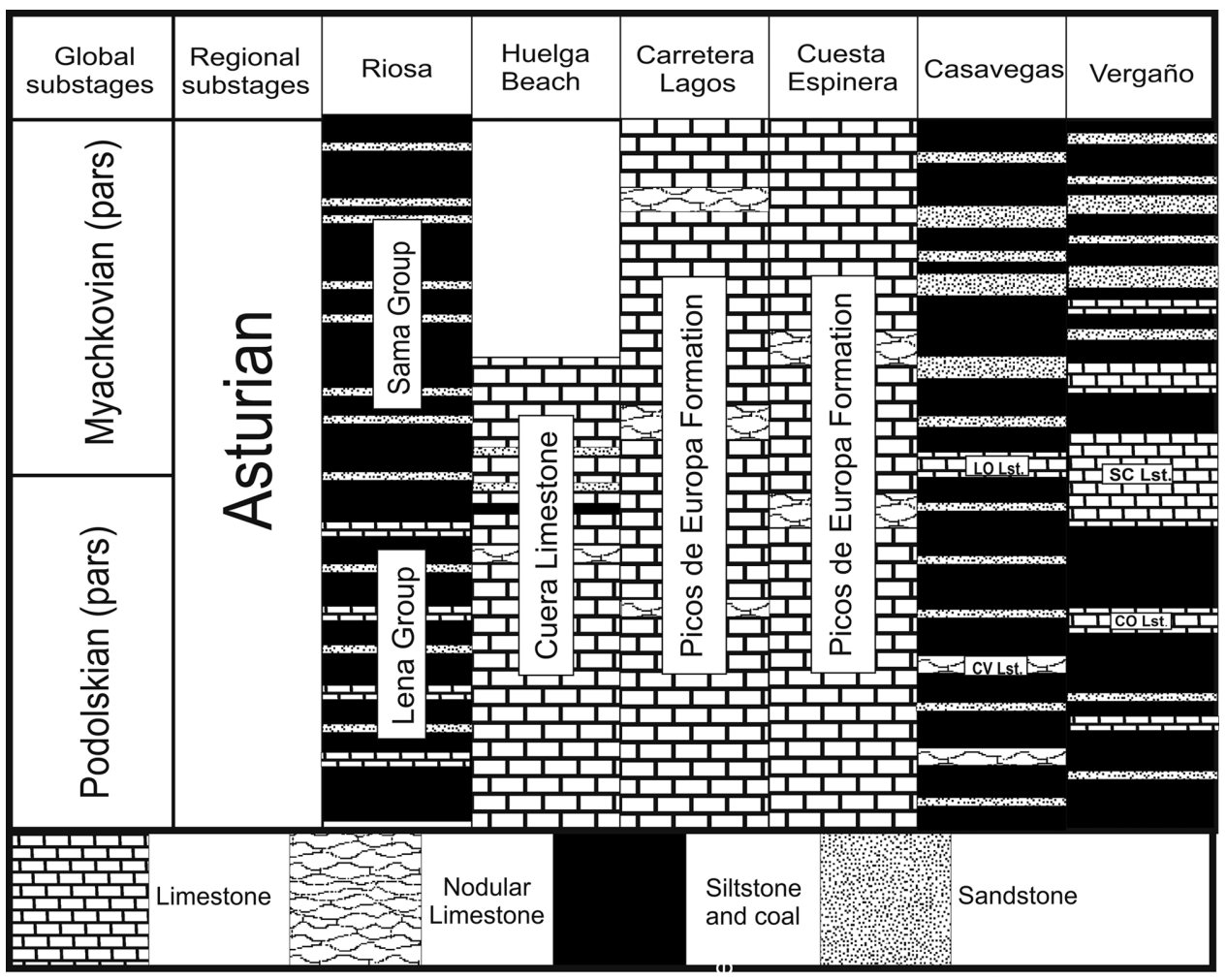

Figure 2. Lithostratigraphic succession at the studied outcrops. Abbreviations: CO Lst: Cotarraso Limestone, SC Lst: Sierra Corisa Limestone, CV Lst: Casavegas Limestone, LO: Lores Limestone.

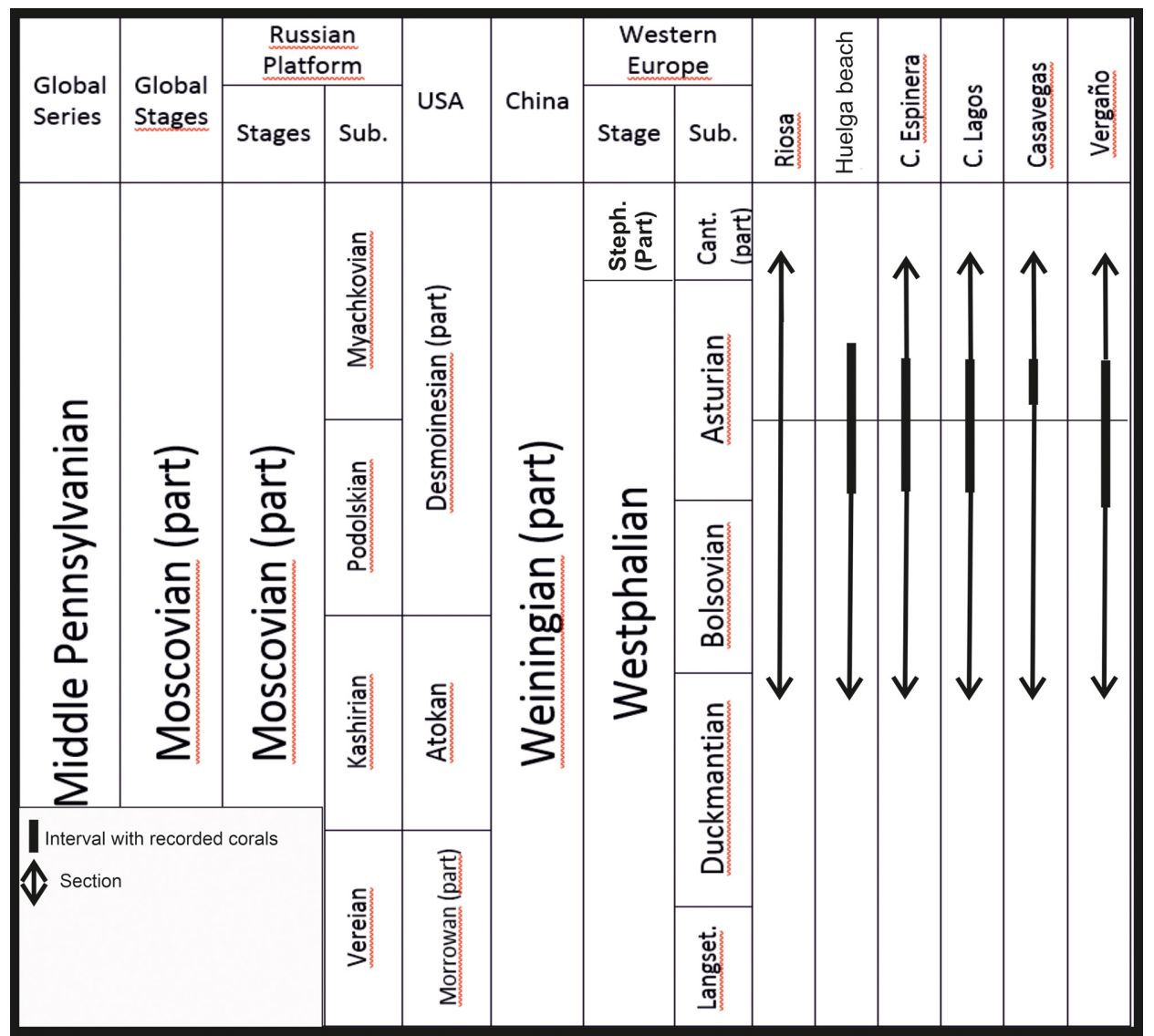

Figure 3. Stratigraphical chart showing the extension of the outcrops yielding Asturian corals. Abbreviations: Langset. = Langsettian; Cant. $=$ Cantabrian; Steph. $=$ Stephanian. 
part of the Weiningian stage in China (Richards, 2013) (Fig. 3).

The studied outcrops are located mainly in the eastern part of the Cantabrian Mountains, in the Palencia and Asturias provinces. They include the following sections (Figs. 1-3): Cuera limestone in the Playa de la Huelga (Huelga Beach) and Cuevas de Mar sections (Rodríguez, 1984; Navarro et al., 1986; Rodríguez and Ramírez, 1987; Coronado and Rodríguez, 2014), Picos de Europa Formation in the type area, mainly near Covadonga Carretera Lagos and Cuesta Espinera sections, (Rodríguez, 1984; Rodríguez and Kullmann 1999), Sierra Corisa Limestone, Cotarraso Limestone, Casavegas Limestone and other limestone units of the Vergaño Fomation at the Palentine area (De Groot, 1963; Rodríguez and Kullmann, 1990).

\section{Coral assemblages}

The Pennsylvanian corals of the Cantabrian Mountains have been studied by De Groot (1963, and in Winkler Prins, 1971), Boll (1985), Rodríguez (1984), Rodríguez et al. (1986), Rodríguez and Kullmann (1990, 1999), Rinklef (1994), Fernández et al. (1995) and Coronado and Rodríguez (2014). The published data are summarised in Fig. 4.

Coral distribution is often conditioned by environments because some types of corals need shallow, warm, clean and agitated waters for living. This is true for hermatypic corals, but we have no control in the Palaeozoic corals on possible symbiosis with algae, the presence of hermatypic corals can't be confirmed in the Carboniferous. But some inferences can be made. Hill (1938-41) proposed three types of corals having different environmental needs. Most colonial rugosans and some colonial tabulates lived mainly in reefal environments and in shallow platforms from tropical areas. We can infer that they were hermatypic. On the contrary, the Cyathaxonia fauna, composed of small undissepimented corals (and some small tabulate colonies) were regarded as living in deep water environments (Hill, (1938-41). However, the record of those corals is wider, because they can also occur in shallow water that were not appropriate for colonial corals because of restricted, turbid or cold conditions. An intermediate fauna composed of solitary dissepimented rugosans may share environments with the two above-mentioned types. The undissepimented corals show usually wide geographical distributions and occur in different facies; but they are very conservative from the evolutionary point of view and many of them have long stratigraphic ranges. On the contrary, colonial corals evolved quite quickly (strong adaptation to environment) but show narrower geographic distributions. That is the reason for the low utility of corals as biostratigraphic markers. Nevertheless, in stressful conditions, such as those during the Asturian time, the solitary corals also show quick changes for adaptation to environment. They evolve quite quickly and may be used as biostratigraphic markers.

In the Asturian from the Cantabrian Mountains, the presence of changing environments allows to use the corals as a tool in characterizing that substage. In some studied sections, where environment was mainly shallow waters, colonial corals are dominant, but frequent solitary corals occur associated with them. It allows comparison with assemblages of deeper water or muddier facies.

The assemblages from Cuera limestone (Playa de la Huelga, and Cuevas de Mar sections, shallow platform with occasional reefal facies) are dominated by massive and fasciculate rugose and tabulate corals

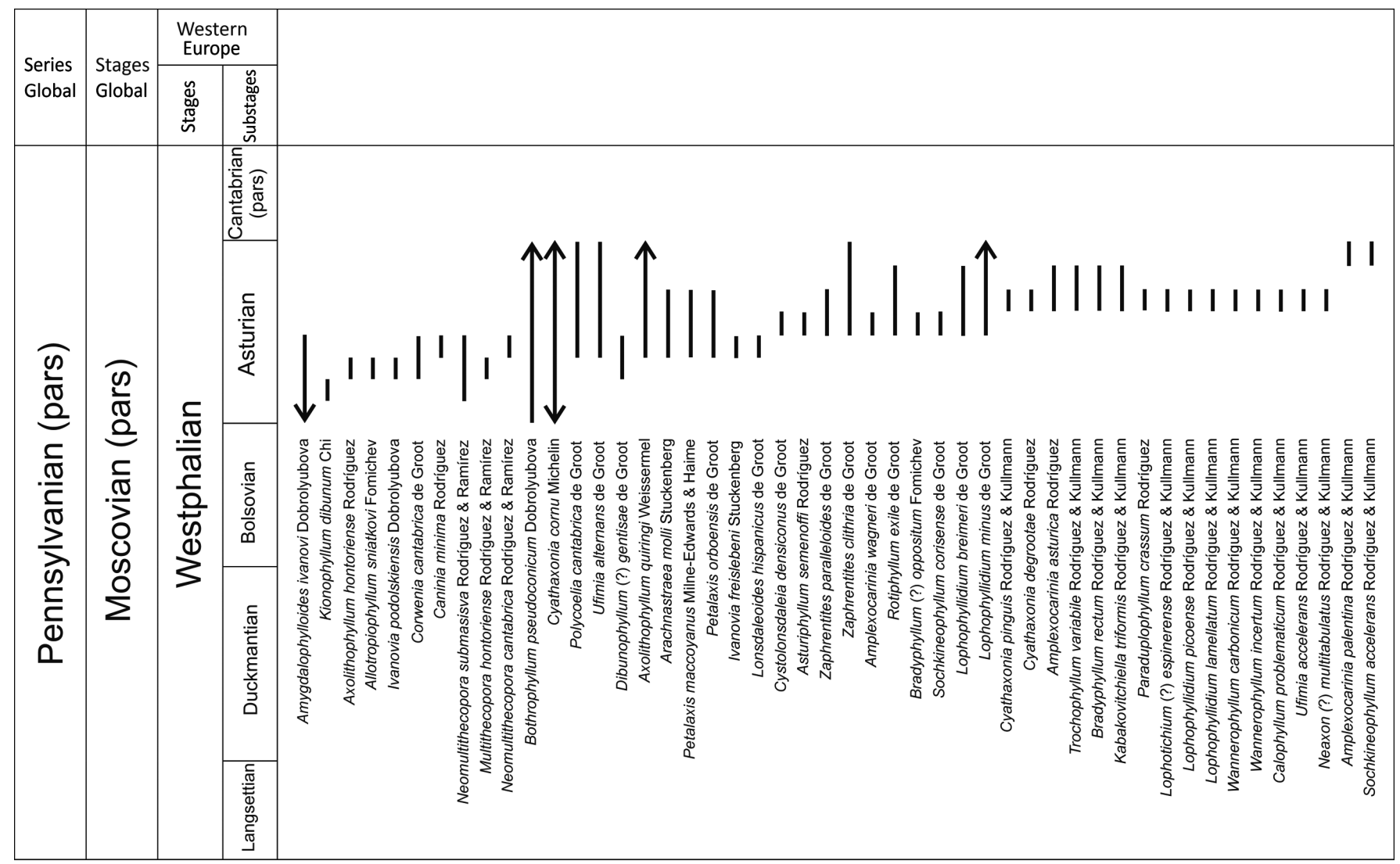

Figure 4. Stratigraphical distribution of the named species in the Asturian from Cantabrian Mountains. 
(Ivanovia podolskiensis Dobrolyubova, Corwenia cantabrica De Groot, Arachnastraea molli Stuckenberg, Multithecopora hontoriense Rodríguez and Ramírez, Neomultithecopora submassiva Rodríguez and Ramírez and $N$. cantabrica Rodríguez and Ramírez). But solitary corals are also common, both dissepimented (Amygdalophylloides ivanovi Dobrolyubova, Kionophyllum dibunum Chi, Axolithophyllum hontoriense Rodríguez, Caninia minima Rodríguez, Bothrophyllum pseudoconicum Dobrolyubova, Bothroclisia sp., Asturiphyllum semenoffi Rodríguez) and undissepimented (Allotropiophyllum sniatkovi Fomichev, Cyathaxonia cornu Michelin, Trochophyllum? sp., Rotiphyllum exile De Groot).

The assemblages from Picos de Europa Formation (Carretera Lagos and Cuesta Espinera sections, outer platform and slope deposits) are completely dominated by very diverse undissepimented corals (Cyathaxonia cornu, C. degrootae Rodríguez, C. pinguis Rodríguez, Amplexocarinia asturica Rodríguez, Trochophyllum variabile Rodríguez and Kullmann, Neaxon? multitabulatus Rodríguez and Kullmann, Duplocarinia sp., Paraduplophyllum crassum Rodríguez, P. sp., Kabakovitchiella triformis Rodríguez and Kullmann, Lophotichium? espinerense Rodríguez and Kullmann, Lophophyllidium breimeri De Groot, L. picoense Rodríguez and Kullmann, L. lamellatum Rodríguez and Kullmann, Wannerophyllum carbonicum Rodríguez and Kullmann, Plerophyllum sp., Ufimia accelerans Rodríguez and Kullmann, Tachylasma sp., Calophyllum problematicum Rodríguez and Kullmann, Bradyphyllum rectum, Bradyphyllum. sp., Rotiphyllum exile De Groot and Zaphrentoides sp.). Neither colonial nor dissepimented solitary corals have been recorded there.

The assemblages from North Palencia (Vergaño Formation and equivalents in the Casavegas Syncline) are very diverse. The Cotarraso limestone, regarded as shallow platform deposits with interbedded siliciclastics yielded colonial corals (Arachnastraea molli Stuckenberg, Corwenia cantabrica De Groot, Petalaxis maccoyanus MilneEdwards and Haime, Petalaxis orboensis De Groot, Lonsdaleoides hispanicus De Groot and Ivanovia freislebeni Stuckenberg), solitary dissepimented (Dibunophyllum? gentisae De Groot, Axolithophyllum quiringi Weissermel, Amygdalophylloides ivanovi Dobrolyubova) and solitary undissepimented corals (Cyathaxonia cormu Michelin, Polycoelia cantabrica De Groot, Ufimia alternans De Groot, Lophophyllidium $\mathrm{sp}$,). The Sierra Corisa limestone, regarded as a main incursion of calcareous platform into deltaic deposits, shows assemblages dominated by solitary undissepimented corals (Cyathaxonia cornu Michelin, Cyathaxonia degrootae Rodríguez, Rotiphyllum exile De Groot, Bradyphyllum? oppositum De Groot, Amplexocarinia wagneri De Groot, Sochkineophyllum corisense De Groot, Ufimia alternans De Groot, Lophophyllidium breimeri De Groot, Lophophyllidium minus De Groot, Zaphrentites paralleloides De Groot, Zaphrentites clithria De Groot). However, it also yielded some solitary dissepimented (Bothrophyllum pseudoconicum Dobrolyubova, Axolithophyllum quiringi Weissermel) and colonial corals (Arachnastraea molli Stuckenberg, Petalaxis orboensis De Groot, Cystolonsdaleia densiconus De Groot). The Casavegas limestone is a thin, marly bed in a mainly siltstone and sandstone sequence containing also coal seams. It is partly equivalent to the Sierra Corisa Limestone. It yielded a quite diverse assemblage composed only of undissepimented corals (Amplexocarinia palentina Rodríguez and Kullmann, Cyathaxonia cornu Michelin, Zaphrentites clithria De Groot, Calophyllum cantabricum Rodríguez and Kullmann,
Sochkineophyllum accelerans Rodríguez and Kullmann, Ufimia alternans De Groot, Lophophyllidium minus De Groot).

\section{Discussion}

The whole assemblage from the Asturian substage in Cantabrian Mountains is composed of 48 named species (Fig. 4) plus about 20 additional species described in open nomenclature. It means a high diversity comparing with other Pennsylvanian substages (Rodríguez et al., 1986).

Few investigations have been completed on Pennsylvanian corals from Western Palaeotethys and indeed less in other more distant geographic zones. Consequently, it is difficult to establish whether the many species recorded from the Asturian substage in Cantabrian Mountains are restricted to this stage or have longer ranges; but some facts can be stated. Their abundance, diversity and the restricted stratigraphic distribution of most of them show significant potential for the age determination and correlation of the Asturian rocks. For a good chronostratigraphic resolution, a coral biostratigraphic scale must be compared with other fossil groups. Fortunately, the time scale for the Asturian substage is well established with fusulinids and conodonts (Villa, 1995; Villa and Van Ginkel, 2000; Méndez, 1990, 2002, 2006; Wagner et al., 2002), which allows a precise stratigraphic location of corals. Thus, they can be used in conjunction with other fossils or separately for dating of Asturian substage (Rodríguez et al., 1986).

Based on this most up-to-date compilation and assessment of data herein, it is recognised that several coral species are restricted to the Asturian substage and they are common in various outcrops from different areas in the Cantabrian Mountains. The most diagnostic species are Amplexocarinia asturica, Cyathaxonia degrootae, Rotiphyllum exile, Ufimia alternans, Lophophyllidium breimeri, Corwenia cantabrica, Amygdalophylloides ivanovi, Kionophyllum dibunum and Neomultithecopora cantabrica (Fig. 5). They occur in several outcrops and sometimes in abundance and represent the coral bulk for the identification of the Asturian, because all these species occur only in that substage. Moreover, some of them have been identified in other areas of the Palaeotethys and may form the basis for wider correlations (Heritsch, 1936; Dobrolyubova, 1937; Fomichev, 1953; Kora and Mansour, 1991).

Some other species occur also in the Kasimovian, but they are not recorded in older strata than Podolskian/Asturian in the Cantabrian Mountains (i.e., Bothrophyllum pseudoconicum, Lophophyllidium. picoense, Lophophyllidium minus, Paraduplophyllum sp.). They may be also important for correlations. Consequently, the whole assemblage is easily distinguishable from the Kashirian and older assemblages.

There are some difficulties to correlate the coral assemblages within the Cantabrian Mountains and with external areas. The environment generates a strong control on the distribution of coral faunas. Corals are common in different facies in the Asturian from Cantabrian Mountains. Assemblages recorded in marls that were sedimented in waters with high turbidity are dominated by solitary undissepimented corals. On the contrary, assemblages recorded in limestones that were sedimented in cleaner waters and were associated to algae, are dominated by solitary dissepimented and colonial corals. However, a mixture of undissepimented, solitary dissepimented and colonial corals 
Table 1. Distribution of rugose and tabulate coral genera in the Asturian substage from selected areas

\begin{tabular}{|c|c|c|c|c|c|c|c|c|}
\hline & N. Am. & Cant. & Carn. & S. Pal. & Don. & Ur.-Arc. & E. Asia & Jap. \\
\hline Actinophrentis & $\mathrm{x}$ & $\mathrm{x}$ & & $\mathrm{x}$ & $\mathrm{x}$ & & & \\
\hline Allotropiophyllum & & & $\mathrm{x}$ & & $\mathrm{x}$ & & & \\
\hline Amandophyllum & $\mathrm{x}$ & & $\mathrm{x}$ & & & & & \\
\hline Amplexocarinia & $\mathrm{x}$ & $\mathrm{x}$ & $\mathrm{x}$ & & & $\mathrm{x}$ & $\mathrm{x}$ & \\
\hline Amygdalophylloides & & $\mathrm{x}$ & & $\mathrm{x}$ & & & $\mathrm{x}$ & \\
\hline Arachnastraea & & $\mathrm{x}$ & & & & & $\mathrm{x}$ & \\
\hline Asturiphyllum & & $\mathrm{x}$ & & & & & & \\
\hline Axolithophyllum & $\mathrm{x}$ & $\mathrm{x}$ & $\mathrm{x}$ & & $\mathrm{x}$ & & $\mathrm{x}$ & \\
\hline Barytichisma & $\mathrm{x}$ & & & & $\mathrm{x}$ & & & \\
\hline Bothrophyllum & $\mathrm{x}$ & $\mathrm{x}$ & $\mathrm{x}$ & $\mathrm{x}$ & $\mathrm{x}$ & $\mathrm{x}$ & $\mathrm{x}$ & $\mathrm{x}$ \\
\hline Bradyphyllum & $\mathrm{x}$ & $\mathrm{x}$ & $\mathrm{x}$ & & $\mathrm{x}$ & & $\mathrm{x}$ & \\
\hline Calophyllum & & $\mathrm{x}$ & & & & & $\mathrm{x}$ & \\
\hline Caninia & $\mathrm{x}$ & $\mathrm{x}$ & $\mathrm{x}$ & & $\mathrm{x}$ & $\mathrm{x}$ & $\mathrm{x}$ & $\mathrm{x}$ \\
\hline Carinthiaphyllum & & & & & & & & $\mathrm{x}$ \\
\hline Chielasma & & & & & & & $\mathrm{x}$ & \\
\hline Cladochonus & $\mathrm{x}$ & & & & & & & \\
\hline Corwenia & $\mathrm{x}$ & $\mathrm{x}$ & & & & & & \\
\hline Cyathaxonia & & $\mathrm{x}$ & & & & & $\mathrm{x}$ & \\
\hline Cystolonsdaleia & $\mathrm{x}$ & $\mathrm{x}$ & & & $\mathrm{x}$ & & $\mathrm{x}$ & \\
\hline ?Dibunophyllum & $\mathrm{x}$ & $\mathrm{x}$ & & & & & $\mathrm{x}$ & \\
\hline Donophyllum & & & $\mathrm{x}$ & & $\mathrm{x}$ & & & \\
\hline Echigophyllum & & & & & & & & $\mathrm{x}$ \\
\hline Fomichevella & & & & & & $\mathrm{x}$ & $\mathrm{x}$ & $\mathrm{x}$ \\
\hline Huangia & & & & & & & $\mathrm{x}$ & \\
\hline Ivanovia & & $\mathrm{x}$ & & & $\mathrm{x}$ & $\mathrm{x}$ & $\mathrm{x}$ & $\mathrm{x}$ \\
\hline Kabakovitchiella & & $\mathrm{x}$ & & & & & & \\
\hline Kionophyllum & $\mathrm{x}$ & $\mathrm{x}$ & $\mathrm{x}$ & & & $\mathrm{x}$ & $\mathrm{x}$ & \\
\hline Koninckocarinia & & & & & & $\mathrm{x}$ & & $\mathrm{x}$ \\
\hline Leonardophyllum & $\mathrm{x}$ & & & & & & & \\
\hline Lonsdaleoides & & $\mathrm{x}$ & & & & & & \\
\hline Lophophyllidium & $\mathrm{x}$ & $\mathrm{x}$ & $\mathrm{x}$ & & $\mathrm{x}$ & $\mathrm{x}$ & $\mathrm{x}$ & $\mathrm{x}$ \\
\hline Lophamplexus & $\mathrm{x}$ & & & & & & & \\
\hline Lophotichium & & $\mathrm{x}$ & & & & & & \\
\hline Lytvolasma & & & & $\mathrm{x}$ & & & & \\
\hline Multithecopora & $\mathrm{x}$ & $\mathrm{x}$ & $\mathrm{x}$ & $\mathrm{x}$ & $\mathrm{x}$ & $\mathrm{x}$ & $\mathrm{x}$ & $\mathrm{x}$ \\
\hline Neokoninckophyllum & $\mathrm{x}$ & & & & $\mathrm{x}$ & $\mathrm{x}$ & $\mathrm{x}$ & \\
\hline Neomultithecopora & $\mathrm{x}$ & $\mathrm{x}$ & & & & & & \\
\hline Neosyringopora & $\mathrm{x}$ & & & & & & & \\
\hline Omiphyllum & & & & & & & & $\mathrm{x}$ \\
\hline Orygmophyllum & & & & & $\mathrm{x}$ & $\mathrm{x}$ & & \\
\hline Palaeacis & $\mathrm{x}$ & $\mathrm{x}$ & & & & & & \\
\hline Paraduplophyllum & $\mathrm{x}$ & $\mathrm{x}$ & & & & & & \\
\hline Petalaxis & $\mathrm{x}$ & $\mathrm{x}$ & $\mathrm{x}$ & & $\mathrm{x}$ & $\mathrm{x}$ & $\mathrm{x}$ & $\mathrm{x}$ \\
\hline Polycoelia & & $\mathrm{x}$ & & & & & & \\
\hline Profischerina & & & & & & $\mathrm{x}$ & $\mathrm{x}$ & \\
\hline Pseudopavona & & & & & & & & $\mathrm{x}$ \\
\hline Pseudotimania & $\mathrm{x}$ & & & & & $\mathrm{x}$ & & $\mathrm{x}$ \\
\hline Pseudozaphrentoides & $\mathrm{x}$ & $\mathrm{x}$ & & & & & & $\mathrm{x}$ \\
\hline Rotiphyllum & & $\mathrm{x}$ & & $\mathrm{x}$ & & & $\mathrm{x}$ & \\
\hline
\end{tabular}


Table 1. continued

\begin{tabular}{|c|c|c|c|c|c|c|c|c|}
\hline & N. Am. & Cant. & Carn. & "S. Pal. & Don. & Ur.-Arc. & E. Asia & Jap. \\
\hline Sestrophyllum & & & & & $\mathrm{x}$ & & $\mathrm{x}$ & \\
\hline Skolekophyllum & & & & & & & $\mathrm{x}$ & \\
\hline Sochkineophyllum & & $\mathrm{x}$ & & & & & & \\
\hline Sutherlandia & $\mathrm{x}$ & & & & & & & \\
\hline Syringopora & $\mathrm{x}$ & $\mathrm{x}$ & $\mathrm{x}$ & $\mathrm{x}$ & $\mathrm{x}$ & $\mathrm{x}$ & $\mathrm{x}$ & \\
\hline Taisyakuphyllum & & & & & & & & $\mathrm{x}$ \\
\hline Trochophyllum & & $\mathrm{x}$ & & & & & & \\
\hline Ufimia & & $\mathrm{x}$ & & & & & & \\
\hline Wannerophyllum & $\mathrm{x}$ & $\mathrm{x}$ & & & & & & \\
\hline Yakovleviella & & & & & & $\mathrm{x}$ & & \\
\hline Zaphrentites & $\mathrm{x}$ & $\mathrm{x}$ & & $\mathrm{x}$ & & $\mathrm{x}$ & & \\
\hline Total genera & 29 & 34 & 13 & 8 & 18 & 17 & 25 & 15 \\
\hline Genera in common & 20 & 34 & 10 & 7 & 11 & 9 & 15 & 6 \\
\hline
\end{tabular}

$\mathrm{X}=$ occurrence. $\mathrm{N}$. Am. $=$ North America (Bamber and Fedorowski, 1998), Cant. $=$ Cantabrian Mountains (Rodríguez et al. 1986, Coronado and Rodríguez, 2014). Carn. = Carnic Alps and Balkans (Heritsch, 1936). S. Pal. = Southern Palaeotethys (Egypt, Arabia, Iran) (Kora and Mansour, 1991). Don. $=$ Donetz Basin $($ Fomichev, 1953). Ur.-Arc. $=$ Urals and Arctic (Dobrolyubova, 1937, Kossovaya 1997). E. Asia = Continental East Asia. Jap. = Japan (Kato, 1990).

have been recorded in some outcrops, allowing the correlation between different facies in the Cantabrian Mountains.

Most coral species are endemic from the Cantabrian Mountains, avoiding a detailed correlation at that level with other areas from Palaeotethys (west and east), North-America or Japan. However, at generic level, there are many similarities with assemblages described in all these areas and mainly with those from western and central Palaeotethys (Table 1). Genera such as Amplexocarinia, Amygdalophylloides, Axolithophyllum, Bothrophyllum, Bradyphyllum, Caninia, Cystolonsdaleia, Kionophyllum, Lophophyllidium, Multithecopora, Paraduplophyllum, Petalaxis, Rotiphyllum, Syringopora and Zaphrentites are widespread in those areas. The comparison of their species when carefully studied may allow further correlations in the Asturian stage.

\section{Conclusion}

Coral assemblages are abundant and diverse in the Asturian from Cantabrian Mountains. They occur in different environments and a mixture of undissepimented, solitary dissepimented and colonial corals have been recorded in some outcrops, allowing the correlation between different facies.

Their abundance and diversity as well as the short stratigraphic range of many of them show significant potential for the age identification and correlation of the Asturian rocks. Some species common in different outcrops and facies may be the basis for the characterization of the Asturian substage with corals.

Most species are endemic in Cantabrian Mountains and the correlation with other areas is difficult because of the scarcity of detailed researches in other regions of the Palaeotethys.

However, at the generic level there are significant similarities and deeper studies on the assemblages from other sectors of the Palaeotethys could result in more precise correlations.

\section{Acknowledgements}

This study was funded by project CGL2016-78738-P of the Spanish Government. This study is a contribution to the IGCP 652. The authors much appreciate the time and effort that Ian Somerville and an anonymous reviewer spent in improving a previous version of the manuscript.

\section{References}

Aretz, M., Herbig, H.G., and Wang, X.D., 2020, The Carboniferous Period. In: Gradstein, F.M., Ogg, J.G., Schmitz, M.D., and Ogg, G.M. (Eds.), Geological Time Scale, pp.811-874.

Bamber, E.W., and Fedorowski, J., 1998, Biostratigraphy and systematics of upper Carboniferous cerioid rugose corals, Ellesmere Island, Arctic Canada. Geological Survey of Canada Bulletin, v. 511, pp. 1-127.

Boll, F.C., 1985, Rugose Korallen der Flachwasser-Fazies im Oberkarbon des Kantabrischen Gebirges (Nordspanien), Palaeontographica, Abteilung A, v. 190, pp. 1-81.

Cleal, C.J., Oplustil, S., Thomas, B.A., and Tenchov, Y., 2011, Pennsylvanian vegetation and climate in tropical Variscan Euramerica. Episodes, v. 34, pp.3-12.

Cohen, K.M., Finney, S.C., Gibbard, P.L., and Fan, J.X., 2013, The ICS International Chronostratigraphic Chart. Episodes, v. 36, pp. 199-204.

Colmenero, J.R., Fernández, L.P., Moreno, C., Bahamonde, J.R., Barba, P., Heredia, N., and González, F., 2002, Carboniferous. In: Gibbons, W. et al., (Eds.), The Geology of Spain, Geological Society of London, pp. 93-116.

Comas-Rengifo, M.J., Duarte, L.V., Félix, F.F., García-Joral, F., Goy, A., and Rocha, R.B., 2015, Latest Pliensbachian-Early Toarcian brachiopod assemblages from the Peniche section (Portugal) and their correlation. Episodes, v. 38, pp. 1-7.

Coronado, I., and Rodriguez, S., 2014, Carboniferous auloporids from the Iberian Peninsula: palaeoecology, diversity, and spatio-temporal distribution. Journal of Iberian Geology, v. 40, pp. 61-85. 
Dimitrova, T.K., Zodrow, E.L., Cleal, C.J., and Thomas, B.A., 2010, Palynological evidence for Pennsylvanian (Late Carboniferous) vegetation change in the Sydney Coalfield, eastern Canada. Geological Journal, v. 45, pp. 388-396.

Dobrolyubova, T.A., 1937, Odinochnye korally mjachkovskogo I podolskogo gorizontov srednego karbona Podmoskovnogo basseina. Trudy Paleontologicheski Institut, v. 6, pp. 1-92 (in Russian).

Engel, B.A., 1989, Ballot results. Ballot 2: West European regional stratigraphic classification. Newsletter on Carboniferous Stratigraphy, v.7, pp. 6-8.

Fernández, L.P., Fernández-Martínez, E., Méndez-Bedia, S., Rodríguez, S., and Soto, F., 1995, Devonian and Carboniferous Reefal Facies from the Cantabrian Zone (NW Spain). In: A. Perejón (Eds.), VII International Symposium on Fossil Cnidaria and Porifera: Field trip A, Universidad Complutense, Madrid, $76 \mathrm{p}$.

Fomichev, V.D., 1953, Koralli Rugosa i stratigrafia Sredne i Verkrrne kamennougolnikh i Permskikh oblochenii Donetzkogo basseina. Trudy VSEGEI, v, 1, pp. 1-622.

Gandl, J., 2011. Die Karbon-Trilobiten des Kantabrischen Gebirges (NW Spanien), 5: Trilobiten des hoheren Westfal. Abhandlungen der Senckenberg Gesellschaft fur Naturforschung, v. 569, pp. 1-143.

Groot, G.E. de, 1963, Rugose corals from the Carboniferous of Northern Palencia (Spain). Leidse Geologische Mededelingen, v. 29, pp. 1-123.

Heritsch, F., 1936, Korallen der Moskauer-Gshel und Schwagerinen Stufe der Karnischen Alpen. Palaeontographica, v. 83, pp. 99-162.

Hill, D., 1938-1941, A monograph on the Carboniferous rugose corals of Scotland. Palaeontological Society of London Monograph, Pt. 1, pp.178, Pt. 2, pp. 79-114, Pt. 3, pp. 115-204.

Jongmans, W.J., and Pruvost, P., 1950, Les subdivisions du Carbonifère dans differents centres houillers de l'Europe. Bulletin de la Societè Géologique de France, v.5, pp.335-344.

Kato, M., 1990, Palaeozoic corals, In: Ichikawa, K, Mizutani, S., Hara, I., Hada, S., and Yao, A. (Eds.), Pre-Cretaceous Terranes of Japan, pp. 307-312.

Kora, M., and Mansour, Y., 1991, Carboniferous rugose corals from the western side of the Gulf of Suez, Egypt. Neues Jahrbuch für Geologie und Paläontologie. Monatshefte, v. 1991, pp. 597-614.

Kossovaya, O.L., 1997, Middle and Upper Carboniferous composite zonal sequence based on Rugose corals (western part of Russia). PracePanstwowego Instytutu Geologicznego, v.157, pp. 93-94.

Leyva, F., and Gervilla, M., 1983, Excursión W. El Carbonífero Medio de la Cuenca Central Asturiana y zonas adyacentes. X International congress on Stratigraphy and Geology of Carboniferous. Instituto Geológico y Minero, Madrid, $200 \mathrm{p}$.

Méndez, C.A., 1990, Conodontos del Carbonífero Superior de la Cordillera Cantábrica. Ph.D. Dis. (unpublished). Universidad de Oviedo, 213 p.

Méndez, C.A., 2002, Carboniferous conodonts of the Ponga and Picos de Europa units (Cantabrian Zone, North Spain). In: García-López, S. and Bastida, F. (Eds.), Palaeozoic conodonts from northern Spain. Instituto Geológico y Minero de España, serie Cuadernos del Museo Geominero, v. 1, pp. 207-227.

Méndez, C. A., 2006, Upper Moscovian-Middle Kasimovian conodonts (Pennsylvanian, Carboniferous) from the Las Llacerias section (Cantabrian Zone, north Spain). Geobios, v. 39, pp. 245-254.

Navarro, D, Leyva, F., and Villa, E., 1986, Cambios laterales de facies en el Carbonífero del oriente de Asturias (Cordillera Cantábrica, Norte de España). Trabajos de Geología, v. 16, pp. 87-102.

Oplustil, S., and Cleal, C., 2007, A comparative analysis of some Late Carboniferous basins of Variscan Europe. Geological Magazine, v. 144, pp. 417-448. doi: 10.1017/S0016756807003330

Owens, B., Riley, N.J., and Calver, M.A., 1985, Boundary stratotypes and new stage names for the lower and middle Westphalian sequences in Britain. Compte Rendu X Congrès International de Stratigraphie et Géologie du Carbonifère, Madrid 1983, v. 4, pp. 461-472.

Richards, B., 2013, Current status of the international Carboniferous time scale. In: Lucas, S.J. et al. (Eds.), The Carboniferous-Permian Transition. Bulletin of the New Mexico of Natural History and Science, v. 60, pp. 348-353.

Rinklef, J., 1994, Fazieskontrolle bei Cyathaxonia-Faunen. Eine palökologische Untersuchung an Faunen nicht dissepimentbildender Einzelkorallen (Anthozoa, Rugosa) aus Sedimenten des spanischen Karbon. Unpublished Ph. D. Universität Tübingen, $204 \mathrm{p}$.

Rocha, R.B. da, Mattioli, E., Duarte, L.V., Pittet, B., Elmi, S., Mouterde, R., Cabral, M.C., Comas-Rengifo, M.J., Gómez, J.J., Goy, A., Hesselbo, S.P., Jenkyns, H.C., Littler, K., Mailliot, S., Veiga de Oliveira, L.C., Osete, M.L., Perilli, N., Pinto, S., Ruget, C., and Suan, G., 2016, Base of the Toarcian Stage of the Lower Jurassic defined by the Global Boundary Stratotype Section and Point (GSSP) at the Peniche section (Portugal). Episodes, v. 39, pp. 460-538.

Rodríguez, S., 1984, Corales rugosos del Este de Asturias. Editorial Complutense, Madrid 109/84, pp. 1-529.

Rodríguez, S., and Kullmann J., 1990, Hornförmige Einzelkorallen (Rugosa) aus spätoberkarbonischen flachwasser-Ablagerungen des Kantabrischen Gebirges (Nordspanien). Palaeontographica A, v. 210, pp. 19-40.

Rodríguez, S., and Kullmann, J., 1999, Rugose corals from the upper member of the Picos de Europa Formation (Moscovian, Cantabrian Mountains, NW Spain), Palaeontographica A, v. 252, pp. 23-92.

Rodríguez, S., and Ramírez, C., 1987, Los siringopóridos de la Seccion de la Playa de la Huelga (Carbonífero, Asturias, NW de España). Boletín de la Real Sociedad Española de Historia Natural (Geología), v. 83, pp. $57-82$.

Rodríguez, S., Sando, W.J., and Kullmann, J., 1986, Utility of corals for Biostratigraphic and Zoogeographic analyses of the Carboniferous in the Cantabrian Mountains, Northern Spain Trabajos de Geología, Universidad de Oviedo, 16, pp. 37-60.

Van de Graaf, W.J.E., 1971, Three Upper Carboniferous limestone-rich, high-destructive, delta systems with submarine fan deposits, Cantabrian Mountains, Spain. Leidse Geologische Mededelingen, v. 46, pp. 157-215.

Van Ginkel, A.C., 1965, Carboniferous fusulinids from the Cantabrian Mountains. Leidse Geologische Mededelingen, v. 34, pp. 1-225.

Villa, E., 1995, Fusulináceos carboníferos del este de Asturias (N de España). Biostratigraphie du Paléozoïque, v. 13, pp. 1-261.

Villa, E., and Ginkel, A.C. van, 2000, Some late Moscovian and Kasimovian fusulinaceans from the Las Llacerias section (Cantabrian Mountains, Spain). Journal of Foraminiferal Research, v. 30, pp. 219-243.

Wagner, R.H., and Winkler Prins, C.F., 1985a, Stratotypes of the two lower Stephanian stages, Cantabrian and Barruelian. Compte Rendu X Congrès International de Stratigraphie et de Géologie du Carbonifère, Madrid 1983, v.4, pp. 473-483.

Wagner, R.H., and Winkler Prins, C.F., 1985b, The Cantabrian and Barruelian stratotypes: a summary of basin development and biostratigraphic information. In: Lemos de Sousa, M.J. and Wagner, R.H. (Eds.), Papers on the Carboniferous of the Iberian Peninsula. Anais Faculdade de Ciencias, Universidade do Porto, Supplement to v. 64, pp. 359-410.

Wagner, R.H., Sánchez de Posada, L.C., Martinez Chacon, M.L., Fernandez, L.P., Villa, E., and Winkler Prins, C.F., 2002, The Asturian Stage: a preliminary proposal for the definition of a substitute for Westphalian D. In: Hills, L.V., Henderson, C. M., Bamber, E.W. (Eds.), Carboniferous and Permian of the World. Canadian Society of Petroleum Geologists, Memoir, v.19, pp. 832-850.

Waters, C.N., Somerville, I.D. Jones, N.S., Cleal, C.J., Collinson, J.D., Waters, R.A., Besly, B.M., Dean, M.T., Stephenson, M.H., Davies, J.R., Freshney, E.C., Jackson, D.I., Mitchell, W.I., Powell, J.H., Barclay, W.J., Browne, M. A.E., Leveridge, B.E., Long, S.L., and McLean, D. 2011. A Revised Correlation of Carboniferous Rocks in the British Isles, Geological Society Special Report, 26, 1-186.Winkler-Prins, C.F., 1971, The road section east of Valdeteja with its continuation along the Arroyo de Barcaliente (Curueño Valley. León) (with a "Note on Leonardophyllum leonense sp. nov "by G.E. de Groot. Trabajos de Geología, v. 4, pp. 677-686. 


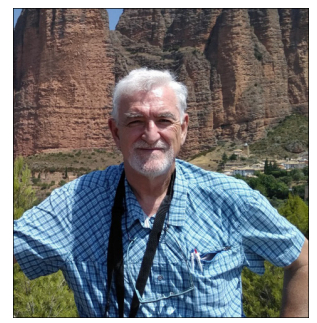

Sergio Rodriguez is Professor in the Complutense University of Madrid since 1981. He spent the years 1984/85 in Tübingen with a Humboldt Research award. His research has been focussed in the Upper Palaeozoic corals and reefs from Spain, Morocco, China, Canada, United States, etc., and has been leader of numerous research projects. Author of more than 200 publications and supervisor of more than 25 Graduate and Ph. D. Thesis. $\mathrm{He}$ is an active member of several scientific societies, being president of the International Association for the Study of Fossil Cnidaria and Porifera (1995-1998) and the Spanish Paleontological Society (2009-2012).

Ismael Coronado is Assistant Professor in the Department of Geography and Geology at León University (Spain) since 2019 and member of Q-GEO group. He got his Doctoral degree in Geology and Geological Engineering at Universidad Complutense (2015) on biomineralization of Carboniferous auloporid corals. He spent three years (2017-2019) as a post-doctoral fellowship at Institute of Paleobiology of Warsaw (Polish Academy of Sciences). His main interest is focused on biomineralization, crystallography and geochemistry of fossils and recent marine calcium carbonate organisms (mainly cnidarians) and their modification during diagenesis. He received the International Award in Palaeontology Research Paleonturología in 2014.

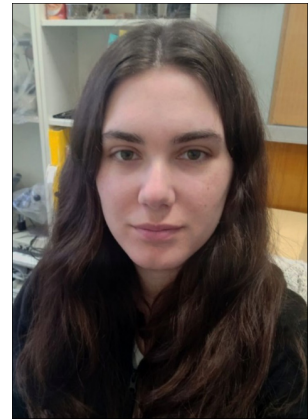

Isabel Rodriguez-Castro is a $\mathrm{PhD}$ student at the Geological Sciences Faculty of the Universidad Complutense de Madrid. She is a member of the Spanish Research Project CGL2016-78738-P and the International Geoscience Programme (IGCP) 635: Reading geologic time in Palaeozoic sedimentary rocks. Her areas of interest include applied palaeontology, sedimentology and stratigraphy, and her research has focused on paleoenvironmental reconstructions and paleogeography. She's also interested in science outreach and communication and has been part of "Geodivulgar: geología y sociedad" project since 2015, participating in and organising several workshops and activities focused on geology outreach. 